\title{
Influence of Organic and Mineral Amendments on Accumulation of Selected Elements in Oat Cultivated on Soil Contaminated with $\mathrm{Cr}$ (III) and $\mathrm{Cr}$ (VI)
}

\author{
Maja Radziemska ${ }^{1}$, Joanna Fronczyk $^{2}$, and Mirosław Wyszkowski ${ }^{3}$
}

\begin{abstract}
Chromium is one of the most phytotoxic heavy metals found in soils, and its concentration is continuously increasing, mainly as a result of anthropogenic activities. The research aimed to determine the influence of $\mathrm{Cr}(\mathrm{III})$ and $\mathrm{Cr}(\mathrm{VI})$ in doses of $0,25,50$, 100 and $150 \mathrm{mgCrkg}^{-1}$ of soil, as well as compost, zeolite and $\mathrm{CaO}$ amendments on the content of trace elements in the grain, shoot and roots of oat. $\mathrm{Cr}(\mathrm{VI})$ modified the content of heavy metals in oat more strongly than $\mathrm{Cr}(\mathrm{III})$. The highest levels of $\mathrm{Cr}$ were found in the treatments polluted with $\mathrm{Cr}(\mathrm{VI})$. All of the investigated heavy metal contents in the tested parts of oat were significantly different in the case of applying compost, zeolite, and $\mathrm{CaO}$ to the soil, as well as increasing concentrations of $\mathrm{Cr}(\mathrm{III})$ and $\mathrm{Cr}(\mathrm{VI})$. $\mathrm{CaO}$ reduced the content of $\mathrm{Zn}$ in oat more strongly than zeolite or compost. The substances introduced to the soil tended to favor the accumulation of $\mathrm{Cu}$ in plants, mainly in oat grain from pots polluted with $\mathrm{Cr}(\mathrm{VI})$. Negative relationships were determined in the grain of oat grown in soil polluted with $\mathrm{Cr}$ (III) and in the roots of oat plants from all test combinations.
\end{abstract}

Keywords - $\mathrm{CaO}$, chromium, compost, contaminated soils, oat, zeolite.

\section{INTRODUCTION}

$\mathrm{S}$ TUDIES on the effects of chromium, especially $\mathrm{Cr}(\mathrm{VI})$, on $\checkmark$ plants are important in every field of environmental protection. Chromium (chemical symbol $\mathrm{Cr}$ ) is a member of a group of transition metals on the periodic table of elements group VIA, with an atomic mass of 51.996, and atomic number of 24. As the tenth element in the Earth's crust, it is omnipresent component in nature; it is found in the air, water and soil, as well as in biological elements. Based on the diagrams of its state of oxidation, the most stable oxidation state is III. The biological activity of chromium depends on its valence state, with $\mathrm{Cr}(\mathrm{III})$ and $\mathrm{Cr}(\mathrm{VI})$ considered to be stable valence forms [1].

Chromium compounds are widely introduced into the

Maja Radziemska ${ }^{1}$ Faculty of Civil and Environmental Engineering, Warsaw University of Life Sciences - SGGW, Nowoursynowska 159, 02-776 Warsaw, Poland

Joanna Fronczyk ${ }^{2}$ Faculty of Civil and Environmental Engineering, Warsaw University of Life Sciences - SGGW, Nowoursynowska 159, 02-776 Warsaw, Poland

Mirosław Wyszkowski ${ }^{3}$ University of Warmia and Mazury in Olsztyn, Faculty of Environmental Management and Agriculture, Pl. Łódzki 4, 10-718 Olsztyn, Poland natural environment in form of various sources, e.g. waste [2], sewage [3], gas contaminants [4], steel slag [5], and products of the leather tanning industry [6] as well as inorganic and organic chemical manufacturing [7]. When passing through the natural environment, they affect all links of the trophic-chain [8].

Chromium can be found in all plant tissues, as an essential microelement responsible for many physiological processes, as well as the activation of certain enzymes, especially oxyreductases. The content of chromium in plants is connected with a set of chemical and geological properties of soil [9]. This means that the $\mathrm{Cr}$ content in plants is dependent on the abundance of this element in soil, as well as the plant species [10], [11], [12]. The chromium content of plants is a topic of interest mainly due to animal feed and dietary issues. In crops intended for consumption, large variation in the content of this element can be observed, e.g.: rapeseed - $1.0 \mathrm{mg} \mathrm{kg}^{-1} \mathrm{~d}$.w., cucumbers - $0.02 \mathrm{mg} \mathrm{kg}^{-1}$ d.w., oats - $0.55 \mathrm{mg} \mathrm{kg}^{-1}$ d.w. [13].

The objectives of this study were to determine the effects of $\mathrm{Cr}(\mathrm{III})$ and $\mathrm{Cr}(\mathrm{VI})$ on the content of trace elements in the grain, shoot and roots of oat (Avena sativa L.) Moreover, an attempt was also made to determine the ability of organic and mineral amendments i.e., compost, zeolite and $\mathrm{CaO}$, on the content of trace elements in the analyzed parts of oat.

\section{MATERIAL AND METHODS}

\section{A. Plant Growth Experiment}

The impact of zeolite as well as compost and $\mathrm{CaO}$ added to soil contaminated with $\mathrm{Cr}(\mathrm{III})$ and $\mathrm{Cr}(\mathrm{VI})$ on the content of $\mathrm{Cr}$, $\mathrm{Cu}, \mathrm{Zn}$ and $\mathrm{Ni}$ in oat (Avena sativa $\mathrm{L}$.) was assessed under the conditions of a pot experiment in an acclimatized greenhouse at the University of Warmia and Mazury in Olsztyn (Poland). The experiment was set up in $9.5 \mathrm{~kg}$ polyethylene pots, $20 \mathrm{~cm}$ in diameter and $26 \mathrm{~cm}$ high. The pots were maintained in controlled conditions; during the day, the air temperature was $26-28^{\circ} \mathrm{C}$, and approximately ten degrees lower $\left(16-18^{\circ} \mathrm{C}\right)$ at night. Mineral fertilization was applied in the form of aqueous solutions of macro- and micronutrients (in milligrams per kilogram of soil): 110 - N, 50 - P, 110 - K, 50 - Mg, 0.33 - B, 5 - Mn, 5 - Mo. The soil was artificially polluted with aqueous solutions of $\mathrm{Cr}(\mathrm{III})$ in the form of $\mathrm{KCr}\left(\mathrm{SO}_{4}\right)_{2} \cdot 12 \mathrm{H}_{2} \mathrm{O}$, and $\mathrm{Cr}(\mathrm{VI})$ in the form of $\mathrm{K}_{2} \mathrm{Cr}_{2} \mathrm{O}_{7}$, in the following doses: 25, 50, 
100 , and $150 \mathrm{mg} \mathrm{kg}^{-1}$ of soil. Control treatments were also established, where neither amendments nor $\mathrm{Cr}(\mathrm{III})$ or $\mathrm{Cr}(\mathrm{VI})$ compounds were introduced. The test plant was oat, which the US Environmental Protection Agency (US-EPA) recommends as a biomarker for chromium toxicity assessment. The seeds of A. sativa (L.) cv. Kasztan, were obtained from an authorized Seed Production Centre in Olsztyn, Poland (OLZNAS-CN Sp. $\mathrm{z}$ o.o.). Plant density was set at $\mathrm{n}=25$ plants per pot. The plants were watered every other day with distilled water to $60 \%$ of the maximum water holding capacity of the soil by adding deionized water. Aerial (grain and shoot) and underground parts of plants (roots) were harvested for laboratory analyses when fully ripe.

\section{B. Physicochemical Characteristics of Experimental Soil and Amendments}

Non-polluted soils used for plant cultivation were collected at a depth of 0-20 cm from farmland in the vicinity of Olsztyn, Poland. The experimental soil was tested for its physicochemical and nutritional properties before sowing the seeds. It was found to be slightly acidic, with a $\mathrm{pH}$ of 5.5, and contained $7.87 \mathrm{~g} \mathrm{~kg}^{-1}$ Corg., $1.01 \mathrm{~g} \mathrm{~kg}^{-1} \mathrm{~N}, 21.29 \mathrm{mg} \mathrm{kg}^{-1} \mathrm{~N}$ $\mathrm{NH}_{4}{ }^{+}, 2.95 \mathrm{mgkg}{ }^{-1} \mathrm{~N}^{-\mathrm{NO}_{3}}, 90.2 \mathrm{P} \mathrm{mg} \mathrm{kg}^{-1}, 37.9 \mathrm{mg} \mathrm{kg}^{-1} \mathrm{~K}$ and $77.0 \mathrm{mg} \mathrm{kg}^{-1} \mathrm{Mg}$. Other metals $\left(\mathrm{mg} \mathrm{kg}^{-1}\right)$ present were $\mathrm{Cr}$ 12.95, $\mathrm{Cu}-9.01, \mathrm{Zn}-24.25$ and $\mathrm{Ni}-3.99$. The grain size structure was that of light loamy sand (fractions in $\mathrm{mm}:<0.002$ - 0.85\%; 0.002-0.020 - 6.85\%; 0.020-0.050 - 7.19\%; 0.050$0.100-7.06 \% ; 0.100-0.250-34.63 \% ; 0.250-0.500-34.06 \%$; $0.500-1.000-9.36 \% ; 1.000-2.000-0 \%)$, and characterized by the following properties: hydrolytic acidity (HAC) - 26.6 $\mathrm{mmol}(\mathrm{H}+)_{\mathrm{kg}}^{-1}$, total exchange bases (TEB) $-100.0 \mathrm{mmol} \mathrm{kg}^{-1}$, cation exchange capacity (CEC) $-126.6 \mathrm{mmol} \mathrm{kg}^{-1}$ and base saturation (BS) $-79.9 \%$.

TABLE I

CHEMICAL COMPOSITION OF SUBSTANCES USED IN THE EXPERIMENT

\begin{tabular}{lllll}
\hline \multicolumn{1}{c}{ Element } & Unit & Compost & Zeolite & $\mathrm{CaO}$ \\
& & & & \\
\hline Phosphorous & $\mathrm{g} \mathrm{kg}^{-1}$ & 2.32 & 0.11 & 0.10 \\
Potassium & & 1.33 & 23.2 & 0.77 \\
Magnesium & & 1.47 & 0.31 & 2.65 \\
Calcium & & 15.9 & 15.3 & 347 \\
Sodium & & 0.12 & 16.1 & 0.07 \\
Chromium & \multirow{2}{*}{$\mathrm{mgkg}^{-1}$} & 3.48 & 1.81 & 2.70 \\
Copper & & 38.1 & 12.4 & 2.26 \\
Zinc & & 31.8 & 14.7 & 5.14 \\
Nickel & & 18.8 & 408 & 6.64 \\
\hline \hline
\end{tabular}

Three amendments were applied to the soil: compost and zeolite (2\% of dry soil mass), and $50 \% \mathrm{CaO}$ in a dose corresponding to one hydrolytic acidity (HAC), i.e. $1.25 \mathrm{~g} \mathrm{~kg}^{-1}$ of soil. The chemical composition of the substances applied to the soil has been provided in Table I.

\section{Preparation And Analyses Of Plant And Soil Sample}

In the laboratory plant samples were thoroughly rinsed, first with tap water and then with deionized water, to remove dust and soil particles. After oven drying $\left(60^{\circ} \mathrm{C}, 48 \mathrm{~h}\right)$, the plants were weighed and powdered using an analytical mill (A 11 IKA, Germany), and kept at an ambient temperature prior to the chemical analyses. The heavy metal concentrations $(\mathrm{Cr}$, $\mathrm{Cu}, \mathrm{Zn}$ and $\mathrm{Ni}$ ) were determined using flame atomic absorption spectroscopy on a SpecrtAA 240FS atomic absorption spectrophotometer (VARIAN, Australia) using a Sample Introduction Pump System in extracts obtained after the microwave digestion of plant samples in nitric acid $\left(\mathrm{HNO}_{3}\right.$ p.a.) with a concentration of $1.40 \mathrm{~g} \mathrm{~cm}^{-1}$, poured into HP500 Teflon vessels and placed in a MARS 5 microwave oven (CEM Corporation, USA). The mineralization conditions, i.e. the volume of an aliquot, the volume of nitrogen acid and mineralization temperature, were set as described in the methodology found in the Mars 5 Operation Manual.

Soil samples were digested and analyzed using the same reagents. Before setting up the experiment, the following soil properties were determined: the grain size composition of the soil by means of the laser method using a Mastersizer $2000 \mathrm{~m}$, $\mathrm{pH}$ - determined by means of the potentiometric method using an aquatic solution of $\mathrm{KCl}$ at a concentration of $1 \mathrm{M} \mathrm{KCldm}^{-3}$ with a glass electrode and a Handylab $\mathrm{pH} / \mathrm{LF} 12 \mathrm{pH}$ meter (Schott, Germany) hydrolytic acidity (HAC) by Kappen's method, with soil samples treated with $0.5 \mathrm{M} / \mathrm{dm}^{3}$ Ca-acetate solution adjusted to $\mathrm{pH} 8.2$ in the ratio of 1:2.5) [14], total exchangeable bases (TEB-K $\mathrm{K}^{+}, \mathrm{Na}^{+}, \mathrm{Ca}^{2+}$, and $\mathrm{Mg}^{2+}$ ) by Kappen's method, determining individual cations after extraction from the soil with $\mathrm{CH}_{3} \mathrm{COONH}_{4}$ [14], cation exchange capacity (CEC) from the formula: $\mathrm{CEC}=\mathrm{HAC}+\mathrm{TEB}$, and percentage base saturation (V) from the formula: $\mathrm{BS}=100 \mathrm{TEB} / \mathrm{CEC}^{-1}$. Organic matter was determined according to Tiurin's method, after the hot digestion of soil samples with $\mathrm{K}_{2} \mathrm{Cr}_{2} \mathrm{O}_{7}$ and $\mathrm{H}_{2} \mathrm{SO}_{4}$ in the presence of $\mathrm{Ag}_{2} \mathrm{SO}_{4}$ as a catalyst and the titration of $\mathrm{K}_{2} \mathrm{Cr}_{2} \mathrm{O}_{7}$ excess with $\mathrm{FeSO}_{4} /\left(\mathrm{NH}_{4}\right)_{2} \mathrm{SO}_{4} \cdot 6 \mathrm{H}_{2} \mathrm{O}$ [15]. The contents of available phosphorus and potassium were established using the EgnerRiehm method [16], and magnesium using the Schachtschabel method [17].

All glass and polyethylene flaskware were previously soaked for 24 hours in $10 \%(\mathrm{v} / \mathrm{v}) \mathrm{HNO}_{3}$ and rinsed three times with ultra-pure water prior to use. Ultra-pure water (specific resistivity of $18.2 \mathrm{M} \Omega \mathrm{cm}$ ) obtained from a Milli-Q system (Millipore, Bedford, USA) was employed to prepare all of the solutions and standards. The quality control of the heavy metal analyses was performed using certified reference material Sigma Aldrich Chemie GmbH, No. BCR142R. The solutions of metals were prepared by the dilution of certified standard solutions (Fluka, Sigma Aldrich). Stock solutions of metals $\left(1000 \mathrm{mg} \mathrm{L}^{-1}\right)$ were prepared from their nitrate salts.

\section{D.Statistical Analysis}

All statistical analyses were carried out with the Statistica 9.1 Statistical Package. The data were analyzed by threefactorial analysis of variance (ANOVA), considering the treatment as the independent variable. Significant statistical differences in all variables were established between the different treatments by Duncan's multiple range test, at $\mathrm{p}<0.05$. 


\section{RESULTS AND DISCUSSION}

\section{A. Effect of $\mathrm{Cr}(\mathrm{III})$ and $\mathrm{Cr}(\mathrm{VI})$ on the Content of Trace Elements}

The toxic effect of chromium on plants [18] depends on many factors, of which the most important are the degree to which the soil is polluted with this metal and other soil properties, e.g. the content of humus, acidity, sorptive properties, or the presence of certain elements [19]. Chromium accumulated in soil can be easily translocated to the aerial parts of plants and cause many morphological changes, e.g. decreased photosynthesis, chlorosis, necrotic spots, changes in colour, damage to roots, and finally, plant death [20]. Therefore, it is essential to search for effective methods for the neutralization of chromium in soil and the reduction of its influence on crops. The negative effect of chromium compounds on various plants has been widely investigated, e.g. Brassica napus var. oleifera [10], Avena Sativa L. [11], Triticum aestivum L. [18], Solanum nigrum L. and Parthenium hysterophorus L. [21], Daucus carota L. [23]. $\mathrm{Cr}(\mathrm{VI})$ has a stronger negative effect on plants than $\mathrm{Cr}(\mathrm{III})$ [Oliveira et al. 2015]. Fig. 1 shows the chromium (Cr) concentrations in the grain, shoot and root of Avena Sativa $\mathrm{L}$. at the different doses of $\mathrm{Cr}(\mathrm{III})$ and $\mathrm{Cr}(\mathrm{VI})$ added to the soil. The highest value of $\mathrm{Cr}$ in the control series was found in the roots and ranged from 9.72 to $77.82 \mathrm{mg} \mathrm{kg}^{-1}$ d.w. (dry weight), with the lowest in grain, ranging from 0.52 to $2.28 \mathrm{mg} \mathrm{kg}^{-1}$ d.w. $\mathrm{Cr}(\mathrm{VI})$ in the amounts of 50 and $100 \mathrm{mg} \mathrm{kg}^{-1}$ d.w. of soil raised the content of chromium in the roots 18 -fold as compared to the control. The content of this element in the shoot was positively correlated $(\mathrm{r}=0.99)$ with the increasing doses of $\mathrm{Cr}(\mathrm{VI})$, with the highest rate of this contaminant (150 $\mathrm{mg} \mathrm{kg}{ }^{-1}$ of soil) causing an over two-fold increase in the content of chromium in the shoot, compared to the control. According to Kabata-Pendias [13], very sensitive plants, e.g. oat, develop toxic symptoms in response to total chromium contents as low as $1-2 \mathrm{mgCr} \mathrm{kg}^{-1}$ of soil, whereas maize can tolerate up to $8 \mathrm{mgCrkg}^{-1}$ of soil, and tobacco - up to 24 $\mathrm{mgCr} \mathrm{kg}^{-1}$ of soil. In the present study, the highest dose of $\mathrm{Cr}(\mathrm{III})$, i.e. $150 \mathrm{mg} \mathrm{kg}^{-1}$ of soil, caused an 8-fold increase in the concentration of $\mathrm{Cr}$ in the roots $(\mathrm{r}=0.99)$ as compared to the control treatment.

The increasing concentrations of tri- and hexavalent chromium in soil in the series without amendments had a positive effect on the content of $\mathrm{Cu}$ in oat (Fig. 1). The highest value of $\mathrm{Cu}$ in the control series occurred in the grain and ranged from 40.70 to $54.58 \mathrm{mg} \mathrm{kg}^{-1}$ d.w., with the lowest observed in the shoot, ranging from 0.70 to $3.50 \mathrm{mg} \mathrm{kg}{ }^{-1}$ d.w. In the series without amendments, the highest average content of $\mathrm{Cu}$ was found in the grain and roots of plants grown in soil contaminated with $\mathrm{Cr}(\mathrm{III})$. The increasing doses of tri- ( $\mathrm{r}=-$ $0.99)$ and hexavalent chromium $(\mathrm{r}=-0.97)$ contributed to a progressing decline in the concentration of $\mathrm{Cu}$ in the grain. The dose of $\mathrm{Cr}(\mathrm{VI})$ equal to $100 \mathrm{mg} \mathrm{kg}^{-1}$ of soil depressed the content of this element by $64 \%$ when compared to the control treatment. The accumulation of copper in the roots, determined by Zheljazkov and Nielsen [24], was higher than in leaves or flowers of peppermint. This phenomenon can be explained by the defense mechanisms of plants, which protect themselves from the excessive accumulation of copper in aerial parts. In shoots harvested from the series without soil amending substances, $\mathrm{Cr}(\mathrm{III})$ caused a gradual decrease in the content of copper as the rates of contamination increased $(\mathrm{r}=-0.89)$. A reverse tendency occurred when $\mathrm{Cr}(\mathrm{VI})$ was applied, as the increasing rates of this contaminant contributed to increasing concentrations of $\mathrm{Cu}(\mathrm{r}=-0.84)$ in relation to the control.

The concentrations of $\mathrm{Zn}$ in the grain, shoot and roots of oat were significantly shaped by the doses of $\mathrm{Cr}(\mathrm{III})$ and $\mathrm{Cr}(\mathrm{VI})$ (Fig. 1). Zinc demonstrates strong affinity to mineral colloids, and is characterized by a weak tendency to forming complex bonds with organic substance. It is also characterized by high mobility in soil and a high uptake by plants, owing to the fast solubility of compounds in which it appears, especially in an acidic environment [25]. In the present study, the highest values of $\mathrm{Zn}$ in the control series were noted in the grain and shoot, ranging from 91.08 to $112.4 \mathrm{mg} \mathrm{kg}{ }^{-1}$ d.w. and 111.8 to $155.0 \mathrm{mg} \mathrm{kg}^{-1}$ d.w., respectively. The content of $\mathrm{Zn}$ in oat grain was positively correlated with increasing doses of $\mathrm{Cr}(\mathrm{III})$. A reverse dependency occurred in the treatments with $\mathrm{Cr}(\mathrm{VI})$. The tested organs of oat grown in the series without contamination and alleviating substances were characterized by a higher average content of $\mathrm{Zn}$ in the treatments with trirather than hexavalent chromium. Of the analyzed plant organs, the highest content of chromium in the series without soil amending substances was found in the roots. In the treatments contaminated with $\mathrm{Cr}$ (III) applied at a dose of 150 $\mathrm{mg} \mathrm{kg}^{-1}$ of soil, a $22 \%$ higher content of $\mathrm{Zn}$ was observed than in the control treatment. A reverse tendency occurred in the treatments with $\mathrm{Cr}(\mathrm{VI})$, where increasing rates of this pollutant caused a decline in the content of $\mathrm{Zn}$ in oat grain by a maximum of $14 \%(\mathrm{r}=-0.98)$ as compared to the control. $\mathrm{Cr}(\mathrm{VI})$ had a stronger effect than $\mathrm{Cr}(\mathrm{III})$ on the content of $\mathrm{Zn}$ in the oat shoot, depressing it by $27 \%(\mathrm{r}=-0.63)$. $\mathrm{Cr}$ (III) raised the content of $\mathrm{Zn}$ in the shoot and roots of oat, but only when added in amounts of up to $50 \mathrm{mg} \mathrm{kg}{ }^{-1}$ of soil. Chromium (VI) affected the content of $\mathrm{Zn}$ in the shoot and roots of oat more strongly than chromium (III).

Nickel is an essential micronutrient for plants, but in high doses, it reduces the growth of roots and results in disorders in nutrient uptake, nitrogen metabolism and photosynthesis [26]. Alloway [27] claims that the content of nickel in plants depends largely on its concentration and forms available in the soil. Among the analyzed oat organs, the highest average content of nickel was found in the roots, both in the treatments with tri- and hexavalent chromium (Fig. 1). This can be explained by the fact that the roots are the main pathway for trace elements to enter the plant. Increasing doses of $\mathrm{Cr}$ (III) had a negative effect on the content of $\mathrm{Ni}$ in oat grain: $-52 \%$ $(\mathrm{r}=-0.97)$. A reverse tendency was observed in the treatments contaminated with chromium (VI), where, under the influence of its increasing rates, the content of Ni increased by $53 \%$ 
$(\mathrm{r}=0.96)$. Hexavalent chromium had a stronger effect on the content of nickel in oat shoots than $\mathrm{Cr}(\mathrm{III})$. In the series without soil amending substances, the highest rate of this contaminant $\left(150 \mathrm{mg} \mathrm{kg}^{-1}\right.$ of soil) caused a $52 \%$ decline (r=0.73 ) in the content of the above element as compared to the control (no contamination). Under the influence of increasing doses of $\mathrm{Cr}(\mathrm{VI})$, increased $\mathrm{Ni}$ concentration in oat roots was noted $(r=0.96)$.

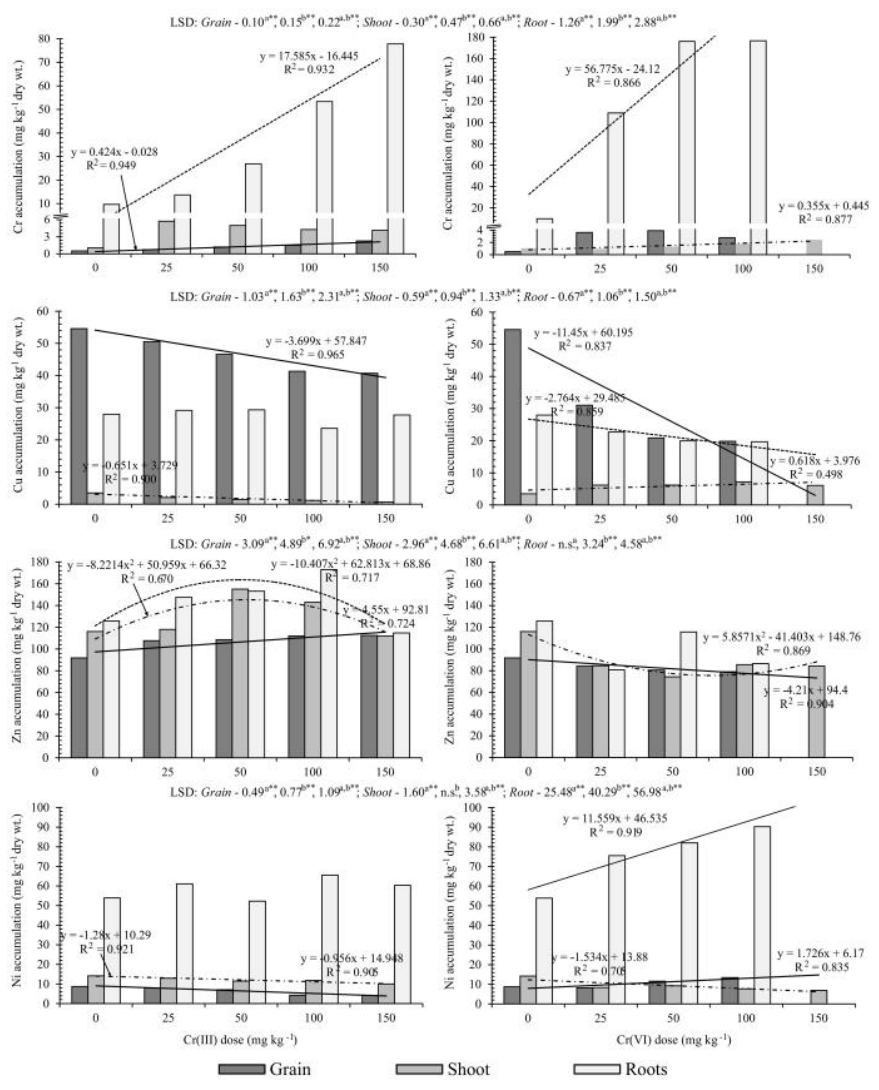

Fig. 1 Effect of $\mathrm{Cr}(\mathrm{III})$ and $\mathrm{Cr}(\mathrm{VI})$ on the content of $\mathrm{Cr}, \mathrm{Cu}, \mathrm{Zn}$, and $\mathrm{Ni}$ in oat (A. sativa L.), in mg dry weight per $\mathrm{kg}$. LSD for: a - type of chromium, b - Cr dose; $\mathrm{c}$ - type of amendments; n.s. - insignificant differences; **significant for $\mathrm{p}=0.01$; significant for $\mathrm{p}=0.05$

\section{B. Effect of Compost, Zeolite and CaO on the Content of Trace Elements}

The application of organic and mineral amendments to contaminated soils can immobilize heavy metals and may provide a sustainable solution for the phytoremediation of, i.a. Cr-contaminants in soils [28]. Numerous studies have shown that the application of rock phosphate [29], halloysite [30], zeolite [31], and diatomite [32], decreased heavy metal solubility and plant uptake in contaminated soils. The present study indicates a strong relationship between the application of compost, zeolite and $\mathrm{CaO}$ and increasing $\mathrm{Cr}(\mathrm{III})$ and $\mathrm{Cr}(\mathrm{VI})$ concentrations of soil on the chromium content of oat (Fig. 2).

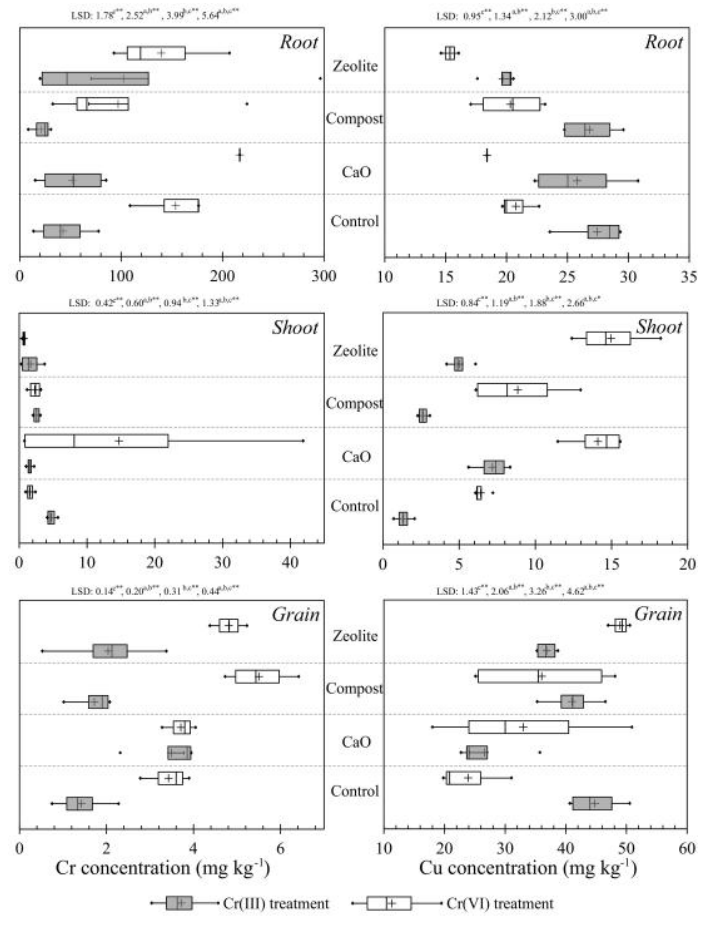

Fig. 2 Boxplots showing the median, quartiles, and minimum and maximum values of $\mathrm{Cr}$ and $\mathrm{Cu}$ in the individual plant organs depending on the type of additive. LSD for: a - type of chromium, b $\mathrm{Cr}$ dose; $\mathrm{c}$ - type of amendments; n.s. - insignificant differences; significant for $\mathrm{p}=0.01$; * significant for $\mathrm{p}=0.05$.

As regards $\mathrm{Cr}(\mathrm{III})$, calcium oxide had the strongest effect, although the other neutralizing substances also caused an decrease in the content of chromium in oat grain. In the treatments with $\mathrm{Cr}(\mathrm{III})$, zeolite and calcium oxide reduced the content of the analyzed element by $65 \%$, and in the pots with $\mathrm{Cr}(\mathrm{VI})$, zeolite reduced its content by $60 \%$ in comparison to the control series. Liming materials, including $\mathrm{CaO}$, are the typical amendment used for in-situ immobilization and to transform soluble metals into residual ones, and to reduce the metal concentration in plant tissues [33]. In another experiment conducted by Radziemska et al. [34], zeolite and halloysite influenced the average content of selected elements in the aerial parts of maize grown on soil contaminated with nickel. In the present study, the influence of compost and $\mathrm{CaO}$ on the content of chromium in the oat shoot in pots with $\mathrm{Cr}(\mathrm{VI})$ was not favorable. A positive effect, that is a reduction in the content of chromium in the oat roots, was determined only after the application of zeolite and $\mathrm{CaO}$ to soil in the $\mathrm{Cr}(\mathrm{VI})$ treatments; compost added to soil polluted with $\mathrm{Cr}$ (III) resulted in an even better effect. However, it should be mentioned that, due to an insufficient amount of plant material, the content of chromium was not determined in oat grain and roots collected from some of the treatments. Heavy metals can be stabilized by mixing inorganic and organic amending agents with, or injecting them into the soil, which decreases their bioavailability. Organic waste, such as sewage sludge and domestic refuse or manure compost, can be used as soil amendments to lower metal availability. 


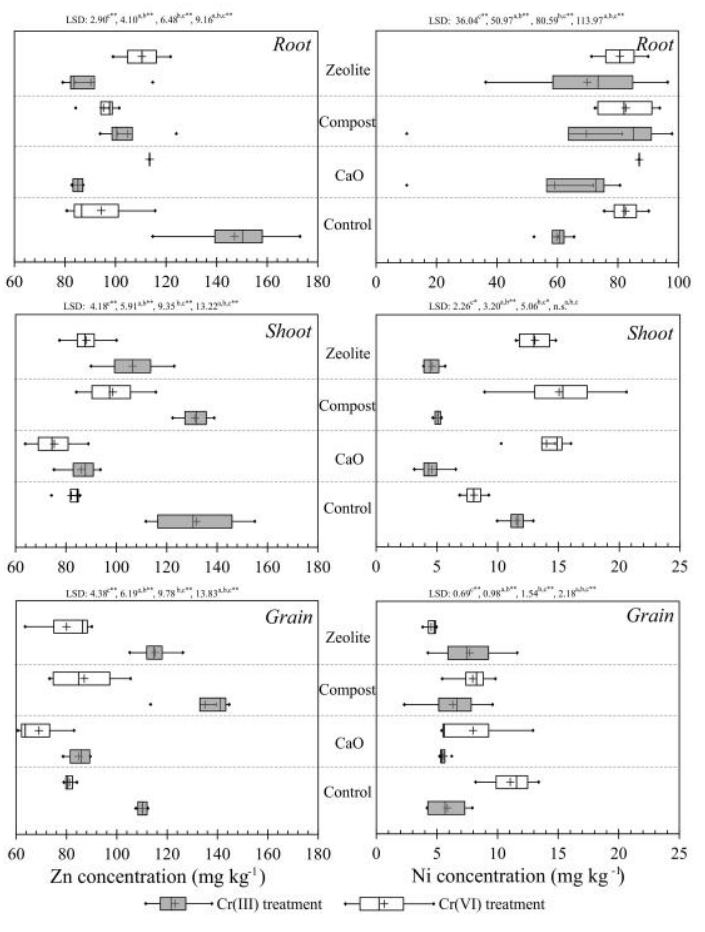

Fig. 3 Boxplots showing the median, quartiles, and minimum and maximum values of $\mathrm{Zn}$ and $\mathrm{Ni}$ in the individual plant organs depending on the type of additive. LSD for: $\mathrm{a}$ - type of chromium, b $\mathrm{Cr}$ dose; $\mathrm{c}$ - type of amendments; n.s. - insignificant differences; *** significant for $\mathrm{p}=0.01$; ${ }^{*}$ significant for $\mathrm{p}=0.05$.

Laboratory and pot trial experiments have clearly demonstrated that the concentration of $\mathrm{Cu}$ in oat was closely correlated with the type of amendments introduced into the soil (Fig. 2). All of the tested substances reduced the content of $\mathrm{Cu}$ in the treatments with trivalent chromium, but a reverse tendency occurred in the analogous series with chromium (VI). In the series with $\mathrm{Cr}(\mathrm{III})$ and $\mathrm{Cr}(\mathrm{VI}), \mathrm{CaO}$, zeolite and, to a lesser degree, compost, caused an increase in the average content of copper in the oat shoots as compared to the control series. The strongest effect on the content of $\mathrm{Cu}$ in the oat roots in the case of chromium (VI) polluted treatments was observed when soil was enriched with $\mathrm{CaO}$ or zeolite. These substances reduced the content of $\mathrm{Cu}$ in oat roots by $24-25 \%$ in relation to the control (no soil amending substances). A weaker, albeit significant, effect of these substances occurred in the treatments with $\mathrm{Cr}(\mathrm{III})$, where the average content of $\mathrm{Cu}$ in oat roots was $14 \%(\mathrm{CaO})$ and $28 \%$ (zeolite) lower than in the series without neutralizing substances.

A stronger effect of the contamination alleviating substances on the content of $\mathrm{Zn}$ in oat grain was observed in the treatments with $\mathrm{Cr}(\mathrm{III})$ than $\mathrm{Cr}(\mathrm{VI})$ (Fig. 3). In the pots with $\mathrm{Cr}(\mathrm{III})$, compost and zeolite raised the content of zinc in oat grain by $23 \%$ and $9 \%$, respectively, as compared to the control (no neutralizing substances). Calcium oxide reduced the content of copper by $24 \%$. The same dependences appeared in the treatments with $\mathrm{Cr}(\mathrm{VI})$, but the range of differences was much smaller. With respect to the oat shoot, the content of $\mathrm{Zn}$ was most strongly affected by soil supplementation with $\mathrm{CaO}$ and, even more so, zeolite in the treatments with chromium
(III), and $\mathrm{CaO}$ in pots with $\mathrm{Cr}(\mathrm{VI})$. By changing the acidity of the soil environment, the availability of $\mathrm{Zn}$ can be modified when the soil is limed [13]. Novo et al. [35] reached the conclusion that technosols made of wastes can be successfully used to increase the growth and the uptake of $\mathrm{Zn}$ by mustards in reclaimed mine soils. In the present series, $\mathrm{CaO}$ reduced the content of $\mathrm{Zn}$ by $36 \%$ - $\mathrm{Cr}(\mathrm{III})$, and 16\% - $\mathrm{Cr}(\mathrm{VI})$. Zeolite and $\mathrm{CaO}$ raised the content of zinc in the roots, but only some of the analyses were performed for these treatments due to insufficient amounts of plant material.

The effect of the neutralizing substances used in the experiment was reflected in the $\mathrm{Ni}$ content of the grain, shoot and roots of oat (Fig. 3). Compost, zeolite and $\mathrm{CaO}$ in the treatments with $\mathrm{Cr}(\mathrm{VI})$ had a negative effect on the mean content of nickel in oat grain. In this series, zeolite decreased the average content of nickel by as much as $57 \%$ when compared to the series without neutralizing substances (control). In another trial by Radziemska et al. [30], zeolite caused the highest (of the analyzed additives) reduction of nickel content in the above-ground parts of maize grown in soil with $240 \mathrm{mgNi} \mathrm{kg}^{-1}$ of soil. The influence of the tested neutralizers was weaker in the treatments with $\mathrm{Cr}$ (III) but, in respect to compost and $\mathrm{CaO}$, analogous to that found in the $\mathrm{Cr}(\mathrm{VI})$ contaminated treatments.

The content of $\mathrm{Ni}$ in the oat shoot in the $\mathrm{Cr}(\mathrm{VI})$ contaminated treatments was positively affected by all of the tested neutralizing substances. The strongest effect was attributed to compost, which increased the average content of nickel by $50 \%$ in the shoot compared to the control series. Organic amendments such as biochar can be used to improve the quality of metal-polluted reclaimed mine soils. Reverse dependencies were found in the pots with $\mathrm{Cr}(\mathrm{III})$. The strongest effect on the average $\mathrm{Ni}$ content in the roots of oat grown in $\mathrm{Cr}$ (III) contaminated soil was produced by compost and $\mathrm{CaO}$, while zeolite had a weaker impact. In the pots polluted with $\mathrm{Cr}(\mathrm{VI})$, zeolite and compost were more effective.

\section{CONCLUSIONS}

Heavy metals concentrations followed the decreasing orders of: $\mathrm{Zn}>\mathrm{Cu}>\mathrm{Ni}>\mathrm{Cr}$ in grain, and $\mathrm{Zn}>\mathrm{Ni}>\mathrm{Cr}>\mathrm{Cu}$ in the shoot and roots. In addition, the content of chromium in oat was higher when the soil contamination with this metal was stronger. $\mathrm{Cr}(\mathrm{VI})$ modified the content of heavy metals in oat more strongly than $\mathrm{Cr}(\mathrm{III})$. The highest levels of $\mathrm{Cr}$ were found in the treatments polluted with $\mathrm{Cr}(\mathrm{VI})$. The content of chromium was particularly high in oat roots, as compared to the grain or shoot. Compost reduced the negative influence of $\mathrm{Cr}$ (III) most significantly, causing a significant decrease in the content of $\mathrm{Cr}$ in the oat shoot and roots. The effects of calcium oxide and zeolite, albeit beneficial, were weaker than that of compost. The highest rates of $\mathrm{Cr}(\mathrm{VI})$ caused an increase in the content of chromium in the grain, shoot and roots of oat, but depressed that of $\mathrm{Cu}$ and $\mathrm{Zn}$. The effects influenced by both forms of chromium on the content of $\mathrm{Ni}$ in oat were less consistent, and depended on the plant organ and dosage of 
chromium. All of the investigated heavy metals in the tested parts of oat differed significantly on application of compost, zeolite, and calcium oxide to the soil, as well as increasing concentrations of $\mathrm{Cr}(\mathrm{III})$ and $\mathrm{Cr}(\mathrm{VI}) . \mathrm{CaO}$ reduced the content of $\mathrm{Zn}$ in oat more strongly than zeolite or compost.

\section{ACKNOWLEDGMENT}

This research was partially supported by Grant no. N305 105933 from Ministry of Science and Higher Education. Warsaw, Poland.

\section{REFERENCES}

[1] A., Maleki, B., Hayati, M. Naghizadeh, and S.W Joo, "Adsorption of hexavalent chromium by metal organic frameworks from aqueous solution," J. Ind. Eng. Chem., vol. 28, pp. 211-216, 2015. http://dx.doi.org/10.1016/j.jiec.2015.02.016

[2] D. Adamcová, M. D. Vaverková, S. Hermanová, and S. Voběrková, "Ecotoxicity of composts containing aliphatic-aromatic copolyesters," Pol. J. Environ. Stud., vol. 24, no. 4, pp. 1497-1505, 2015.

[3] C. Vogel, C. Adam, P. Kappen, T. Schiller, E. Lipiec, and D. Mcnaughton, "Chemical state of chromium in sewage sludge ash based phosphorus-fertilizers," Chemosphere, vol. 103, pp. 250-255, 2014. http://dx.doi.org/10.1016/j.chemosphere.2013.12.012

[4] F. Meshkani, and M. Rezaei, "Hydrogen production by high temperature water gas shift reaction over highly active and stable chromium free Fe-Al-Ni catalysts," Int. J. Hydrogen Energ., vol. 40, pp. 10867-10875, 2015. http://dx.doi.org/10.1016/j.ijhydene.2015.06.170

[5] W. Sas, A. Głuchowski, M. Radziemska, J. Dzięcioł, and S. Szymański, "Environmental and geotechnical assessment of the steel slags as a material for road structure," Materials, vol. 8, pp. 4857-4875, 2015. http://dx.doi.org/10.3390/ma8084857

[6] M. Taghipour, and M. Jalali, "Effect of clay minerals and nanoparticles on chromium fractionation in soil contaminated with leather factory waste,". J. Hazard. Mater., vol. 297, pp. 127-133, 2015. http://dx.doi.org/10.1016/j.jhazmat.2015.04.067

[7] R. Thacher, L. Hsu, V. Ravindran, K. H. Nealson, and M. Pirbazari, "Modeling the transport and bioreduction of hexavalent chromium in aquifers: In fluence of natural organic matter," Chem. Eng. Sci., vol. 138, pp. 5552-565, 2015. http://dx.doi.org/10.1016/j.ces.2015.08.011

[8] M. Radziemska, and J. Fronczyk, "Level and contamination assessment of soil along an expressway in an ecologically valuable area in central Poland," Int. J. Environ. Res. Public Health., vol. 12, pp. 13372-13387, 2015. http://dx.doi.org/10.3390/ijerph121013372

[9] R. A. Gill, L. Zang, B. Ali, M. A., M. A. Farooq, P. Cui, S. Yang, and W. Zhou, "Chromium-induced physio-chemical and ultrastructural changes in four cultivars of Brassica napus L.," Chemosphere, vol. 120, pp. 154-164, 2015. http://dx.doi.org/10.1016/j.chemosphere.2014.06.029

[10] M. Wyszkowski, and M. Radziemska, "The effect of chromium (III) and chromium (VI) on the yield and content of nitrogen compounds in plants,". J. Toxicol. Environ. Heal. A., vol. 73, no. 17, pp. 1274-1282, 2010. http://dx.doi.org/10.1080/15287394.2010.492016

[11] M. Wyszkowski, and M. Radziemska, "Assessment of tri- and hexavalent chromium phytotoxicity on oats (Avena sativa L.) biomass and content of nitrogen compounds," Water Air Soil Poll., vol. 224, pp. 1619-1632, 2013. http://dx.doi.org/10.1007/s11270-013-1619-9

[12] M. Wyszkowski, and M. Radziemska, "Influence of chromium (III) and (VI) on the concentration of mineral elements in oat (Avena sativa L.),". Fresn. Environ Bull., vol. 22, no. 4, pp. 955-961, 2013.

[13] A. Kabata-Pendias, "Trace elements in soils and plants," CRC Press. Boca Raton, FL (4th edition), vol. 505 pp., 2011.

[14] A. Klute, "Methods of soil analysis. American Society of Agronomy," Agronomy Monograph 9, Madison, Wisconsin, USA, 1996.
[15] A. Mocek A., and S. Drzymała, Genesis, analysis and soil classification. Geneza, analiza i klasyfikacja gleb (in Polish). Poznań University of Life Sciences, CA: Poznań, 2010.

[16] H. Egner, H. Riehm, and W. R. Domingo, Untersuchungen über die chemische Bodenanalyse als Grundlage für die Beurteilung des Nährstoffzustandes der Böden. II. Chemische Extractionsmethoden zur Phospor- und Kaliumbestimmung. Annals Royal Agricultural College 26, CA: Sweden, 1960, pp. 199-215.

[17] E. Schlichting, H. P. Blume, and K. Stahr, Bodenkundliches Praktikum. Pareys Studientexte 81. Blackwell Wissenschafts-Verlag, CA: Berlin, 1995.

[18] M. Adrees, S., Ali, M. Iqbal, S. A. Bharwana, Z. Siddiqi, M. Farid, Q. Ali, R. Saeed, and M. Rizwan, "Mannitol alleviates chromium toxicity in wheat plants in relation to growth, yield, stimulation of anti-oxidative enzymes, oxidative stress and $\mathrm{Cr}$ uptake in sand and soil media,". Ecotoxicol. Environ. Saf., vol. 122, pp. 1-8, 2015. http://dx.doi.org/10.1016/j.ecoenv.2015.07.003

[19] M. Wyszkowski, and M. Radziemska, "The effect of chromium content in soil on the concentration of some mineral elements in plants,". Fresen. Environ. Bull., vol. 18, no. 7, pp. 1039-1045, 2009.

[20] I. E. Zaheer, S. Ali, M, Rizwan, M. Farid, M. B. Shakoor, R. A. Gill, U. Najeeb, N. Iqbal, and R. Ahmad, "Citric acid assisted phytoremediation of copper by Brassica Napus L.," Ecotoxicol. Environ. Saf., vol. 120, pp. 310-317, 2015. http://dx.doi.org/10.1016/j.ecoenv.2015.06.020

[21] I. Uddin, A. Bano, and S. Masood, "Chromium toxicity tolerance of Solanum nigrum L. and Parthenium hysterophorus L. plants with reference to ion pattern, antioxidation activity and root exudation," Ecotox. Environ. Saf., vol. 113, pp. 271-278, 2015. http://dx.doi.org/10.1016/j.ecoenv.2014.12.014

[22] C. Ding, X. Li, T. Zhang, Y. Ma, and X. Wang, "Phytotoxicity and accumulation of chromium in carrot plants and the derivation of soil thresholds for Chinese soils,". Ecotox. Environ. Saf., vol. 108, 179-186, 2015.

http://dx.doi.org/10.1016/j.ecoenv.2014.07.006

[23] L. M. Oliveira, J. T. Lessl, J. Gress, R. Tisarum, L. R. G. Guilherme, and L. Q. Ma, "Chromate and phosphate inhibited each other's uptake and translocation in arsenic hyperaccumulator Pteris vittata L.," Environ. Poll., vol. 197, pp. 240-246, 2015. http://dx.doi.org/10.1016/j.envpol.2014.11.009

[24] D. V. Zheljazkov, and N. E. Nielsen, "Studies on the effect of heavy metals $(\mathrm{Cd}, \mathrm{Pb}, \mathrm{Cu}, \mathrm{Mn}, \mathrm{Zn}$ and $\mathrm{Fe})$ upon the growth, productivity and quality of lavender (Lavendula angustifokia Mill.) production," $J$. Essent. Oil Res., vol. 8, no. 3, pp. 258-274, 1996. http://dx.doi.org/10.1080/10412905.1996.9700612

[25] D. Mani, C. Kumar, and N. K. Patel, "Integrated micro-biochemical approach for phytoremediation of cadmium and zinc contaminated soils," Ecotoxicol. Environ. Saf., vol. 111, pp. 86-95, 2015. http://dx.doi.org/10.1016/j.ecoenv.2014.09.019

[26] V. Oláh, A. Hepp, and I. Mészáros, "Comparative study on the sensitivity of turions and active fronds of giant duckweed (Spirodela polyrhiza (L.) Schleiden) to heavy metal treatments," Chemosphere., vol. 132, pp. 40-46, 2015. http://dx.doi.org/10.1016/j.chemosphere.2015.01.050

[27] B. J. Alloway, Heavy metals in soils. Blackie and Sons, CA: Glasgow, 1990, pp. 83-99.

[28] Y. Sun, Q. T. Wu, C. C. C. Lee, B. Li, and X. Long, "Cadmium sorption characteristics of soil amendments and its relationship with the cadmium uptake by hyperaccumulator and normal plants in amended soils," Int. J. Phytorem., vol. 16, no. 5, pp. 496-508, 2014. http://dx.doi.org/10.1080/15226514.2013.798617

[29] G. Jiang, Y. Liu., L. Huang, Q. Fu, Y. Deng, and H. Hu, „Mechanism of lead immobilization by oxalic acid-activated phosphate rocks," $J$. Environ. Sci., vol. 24, no. 5, pp. 919-925, 2012. http://dx.doi.org/10.1016/S1001-0742(11)60836-X

[30] M. Radziemska, Z. Mazur, J. Fronczyk, and Jeznach, "Effect of zeolite and halloysite on accumulation of trace elements in maize (Zea Mays L.) in nickel contaminated soil," Fresen. Environ. Bull., vol. 23, no. 12a, pp. 3140-3146, 2014.

[31] N. Putwattana, M. Kruatrachue., A. Kumsopac, and P. Pokethitiyook, "Evaluation of organic and inorganic amendments on maize growth and 
uptake of $\mathrm{Cd}$ and $\mathrm{Zn}$ from contaminated paddy soils," Int. J. Phytorem., vol. 17 no. 2 , pp. 165-174, 2015.

http://dx.doi.org/10.1080/15226514.2013.876962

[32] X. Ye., S. Kang, H. Wang, H. Li, Y. Zhang, G. Wang, and H. Zhao, "Modified natural diatomite and its enhanced immobilization of lead, copper and cadmium in simulated contaminated soils," J. Hazardous Mat., vol. 289, pp. 210-218, 2015.

http://dx.doi.org/10.1016/j.jhazmat.2015.02.052

[33] S. M. Shaheen, and J. Rinklebe, "Impact of emerging and low cost alternative amendments on the (im)mobilization and phytoavailability of $\mathrm{Cd}$ and $\mathrm{Pb}$ in a contaminated floodplain soil," Ecol. Eng., vol. 74, pp. 319-326, 2015. http://dx.doi.org/10.1016/j.ecoleng.2014.10.024

[34] M. Radziemska, Z. Mazur, and J. Jeznach, "Influence of applying halloysite and zeolite to soil contaminated with nickel on the content of selected elements in Maize (Zea mays L.)," Chem. Eng. Trans., vol. 32, pp. 301-306, 2013.

[35] L. A. B. Novo, E. F. Covelo, and L. Gonzalez, "Phytoremediation of amended copper mine tailings with Brassica juncea,". Int. J. Min. Reclam. Environ., vol. 27, pp. 215-226, 2013.

http://dx.doi.org/10.1080/17480930.2013.779061 